\title{
УДК 591.5
}

DOI: 10.31651/2076-5835-2018-1-2021-2-80-87

Ярмак Тетяна Леонідівна,

завідувачка зоологічним музеєм кафедри зоології Харківський національний педагогічний університет імені Г.С. Сковороди tanyayarmak77@gmail.com

ORCID: https://orcid.org/0000-0003-0746-4038

Мамедова Юлія Павлівна аспірантка кафедри зоології Харківський національний педагогічний університет імені Г.С. Сковороди turdusphilomelos2017@ukr.net ORCID: https://orcid.org/0000-0002-4047-5946

Чаплигіна Анжела Борисівна, завідувачка кафедрою зоології, докторка біологічних наук, професорка кафедри зоології Харківський національний педагогічний університет імені Г.С. Сковороди iturdus@ukr.net

ORCID: https://orcid.org/0000-0002-3574-5120

\section{ГНІЗДОВА БІОЛОГІЯ ЛИСКИ (Fulica atra L.) НА ВОДООЧИСНИХ СПОРУДАХ МІСТА ХАРКОВА}

Досліджено гніздову біологію лиски (Fulica atra L.) на мулових майданчиках водоочисних споруд комплексу біологічної очистки №2 м. Харків та озері Новий Лиман у квітні-червні 2020-2021 років. Виявлено особливості розміщення 73 гнізд лиски. Перші яйия у

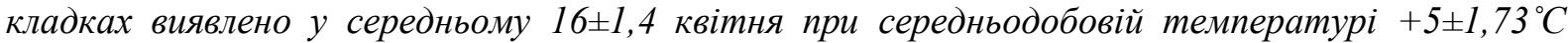
вночі та $+20 \pm 0,89^{\circ} \mathrm{C}$ вдень у 2020 роиі та $18 \pm 1,9$ квітня при $+14,9 \pm 3,08^{\circ} \mathrm{C}$ вдень $i+5 \pm 2,76^{\circ} \mathrm{C}$

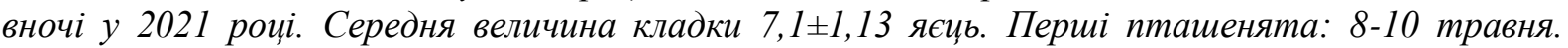

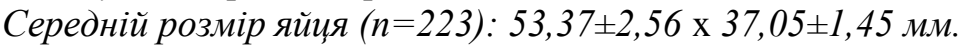
Лиман.

Ключові слова: лиска; гніздова біологія; відкладання яєиь;очисні споруди; озеро Новий

\section{Постановка проблеми. Аналіз останніх публікацій}

Невід'ємним та важливим компонентом водних екосистем є птахи - найбільш лабільні та мобільні представники біоти. Для одних з них антропізація є стабілізуючим чинником, для інших рушійним, особливо відчутно це під час гніздування. Загалом, на фоні загальної загрози для біоти, урбанізація на сьогодні $є$ важливою ареною еволюції видів та процесів адаптації. Механізми антропогенної трансформації автохтонної фауни, iii адаптованості до урбоекологічних умов є важливою науковою проблемою, яка потребує грунтовних досліджень та аналізу отриманих результатів.

Лиска (Fulica atra L.) досить багаточисельний птах водно-болотних угідь, мешкає на річках, озерах та ставках по всій території України $[1,4,6,11,15]$, крім Карпат [16]. Взимку, за відсутності криги, лиска залишається на своїй водоймі [3]. Про зимівлю лиски, як звичайне явище у межах міста Варшава (Польща), відомо ще з 1993 року [8]. В Україні про зимівлю лиски описано у Києві та Київській області [7]. Великі скупчення (більше 20 тис. особин) взимку спостерігались на Дністровських, Утлюкських, Тарханкутських, Сивашських водно-болотних угіддях [4].

Гніздова територіальність лиски (Fulica atra L.) та утворення масових скупчень поза сезоном розмноження, різноманітність і виразність поведінкових реакцій птахів, здавна привертають увагу екологів та етологів $[11,2,10]$. В умовах міста лиска досить пластичний вид. Птахи можуть швидко пристосовуватись до постійної 
присутності людей біля гнізда [13]. У випадку, коли лиска гніздиться у віддалених від населених пунктів місцях, вона досить обережна по відношенню до людини [7].

Мета. Оцінити сучасний стан популяції лиски на водоочисних спорудах та озері Новий Лиман у місті Харків.

\section{Матеріали та методи дослідження}

Дослідження проведені у 2020-2021 р.р. під час експедиційних виїздів на озеро Новий Лиман (4953'29.1"N 36² $15^{\prime} 21.7^{\prime \prime}$ ) та очисні споруди комплексу біологічної очистки №2 м. Харкова. Озеро Новий Лиман - наливне озеро, яке утворилося на місці піщаного кар'єру та розташоване з південно-західної сторони від мулових майданчиків фільтрації очисного комплексу № 2 м. Харкова у південній частині м. Харкова (Україна), його площа становить близько 376 927,96 м², зі східного боку в нього впадає р. Броди.

Об'єкт дослідження - популяція лиски (Fulica atra L, 1758) на озері Новий Лиман та на мулових майданчиках очисних споруд № 2 міста Харкова.

На очисних спорудах № 2 міста Харкова виділені 5 мулових майданчиків, які заселяли лиски. Три майданчика (№№ 5,5 Т, 12) займають північно-східне положення, по відношенню до озера Новий Лиман, розташовані на відстані не більше 944,66 м від його берегів. Їх площа на момент досліджень становила: 3410,85 м $^{2}, 12766,57 \mathrm{~m}^{2}$ та $15389,40 \mathrm{~m}^{2}$ відповідно. Майданчик № 3, площею $14472,12 \mathrm{~m}^{2}$, розташований на південний схід від озера, на відстані не більше 735,08 м. від нього. Майданчик №1 знаходиться із східної сторони, площа ії становить 14200,88 м².

Площі мулових майданчиків та їх периметри виміряні за допомогою Google карти. Графічне зображення розміщення мулових майданчиків представлене на рис. 1.

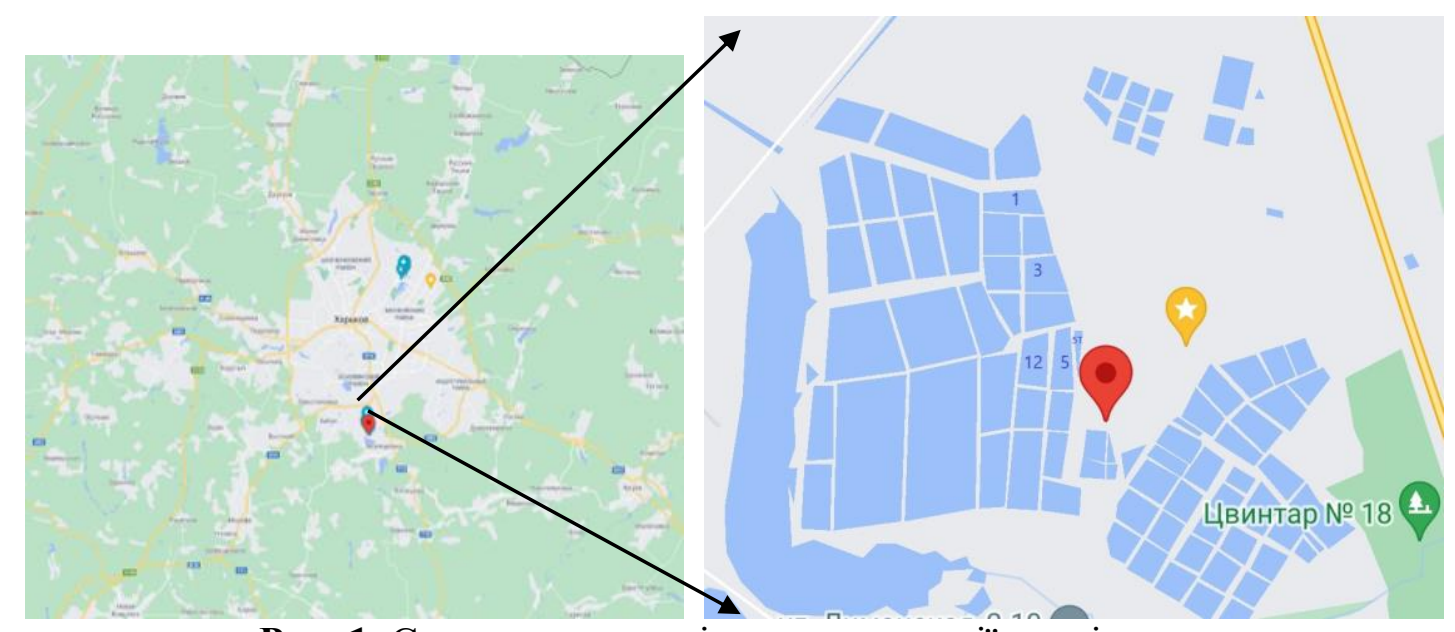

Рис. 1. Схематичне розмішення території досліджень

При проведенні досліджень використані загальноприйняті методи вивчення гніздування водоплавних птахів. Для аналізу гніздового розподілу Fulica atra використані дані маршрутних обліків з берега та байдарки, візуальні спостереження і картування гнізд. Виїзди на озеро здійснювались у квітні-вересні. Знайдено та прослідковано гніздовий цикл 62 гнізд лиски на озері Новий Лиман та 11 гнізд на мулових майданчиках очисного комплексу № 2 м. Харків, яким присвоєні координати та нанесені на карту (Рис.2).

Ступінь насидженості яєць визначали за їх плавучістю [2]. Проведений обрахунок морфометричних параметрів яєць. Визначено лінійні розміри яйця (довжину L i діаметр B); об'єм яйця (V) визначали за формулою Р. Мянда [14]: V=0,51 $\times \mathrm{L} \times \mathrm{B}$, (коефіцієнт 0,51 дає похибку не більше 2\%) [20]; індекс форми округлості яйця $\left(\mathrm{S}_{\mathrm{ph}}\right)$ за формулою: $\mathrm{S}_{\mathrm{ph}}=\mathrm{B} / \mathrm{Lx} 100$. 


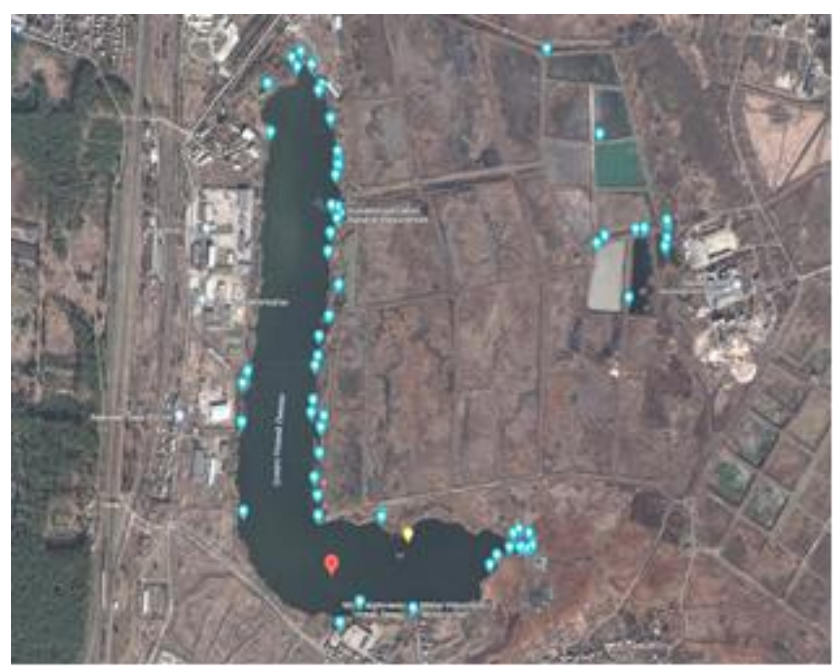

Рис. 2. Карта розміщення гнізд лиски на озері Новий Лиман та мулових майданчиках

Морфометричні параметри яєць визначали 3 допомогою штангенциркуля (точність вимірювання 0,1 мм), розміри гнізда - 3 допомогою рулетки $(1,0 \mathrm{~cm})$.

У статті використані авторські фото.

\section{Результати та їх обговорення}

У місті Харкові лиска (Fulica atra L) мешкає на водоймах природного та антропогенного походження. Важливою умовою гніздування птахів $€$ поєднання невеликої водної поверхні 3 прибережною (часто досить щільною) рослинністю. Прибережна зона озера Новий Лиман поросла густою рослинністю (очерет звичайний (Phragmites australis (Cav.) Trin. ex Steudel), осока парвська (Carex brevicollis DC.), рогіз широколистий (Typha latifolia L.) та ін.), що створює ідеальні умови для гніздування водоплавних птахів. Озеро досить щільно населене навколоводними птахами, серед яких мартин звичайний (Larus ridibundus L. 1758), мартин жовтоногий (Larus cachinnans Pall, 1811), пірникоза велика (Podiceps cristatus L, 1758), пірникоза мала (Podiceps ruficollis Pall, 1764), попелюх (Aythya ferina L, 1758), крижень (Anas platyrhynchos L. 1758) та інші. Лиска є одним із найчисельніших видів, що гніздяться на озері. Більшість гнізд птахи розміщували в смузі торішнього рогозу по один бік озера, щільність гніздування у 2021 році становила 3,6 пар/га.

Для гніздування на мулових майданчиках, лиски обирали порослі рослинністю ділянки, які мали достатню кількість води (Рис. 3). Таким чином, птахи мали нерівномірний розподіл за гніздовими ділянками на мулових майданчиках, ми це пов'язуємо з малою кормовою базою та незначною часткою водного дзеркала. Зокрема, ділянка № 1 у 2020 році, в основному, була утворена муловими відкладеннями (60 \%) та рослинністю (35\%), вода накопичувалась у вигляді «блюдця» $(5 \%)$, після дощу. У 2021 році цей майданчик заріс рослинністю на 85\% і не був заселений лискою.

Мулові майданчики №№ 12, 5, 5Т наповнені водою на 80-95 \%, були заселені як лискою, так й іншими птахами. Зокрема на майданчику № 5 Т разом 3 лискою гніздились курочка водяна (Gallinula chloropus L., 1758) - 3 пари., широконіска північна (Anas clypeata L., 1758) - 3 пари, мартин (Larus ridibundus L., 1766) - 94 пари, крижень (Anas platyrhynchos L., 1758) - 3 пари. Завдяки колективному захисту мартинів звичайних полівидової колонії від луня очеретяного (Circus aeruginosus L), воронових птахів, щільність гніздування на цьому майданчику залишається високою протягом двох років поспіль.

Щільність розмноження лиски на мулових майданчиках у 2021 році становила 0,6 пар/га. Гнізда птахи розміщували на мілководді між негустих минулорічних рослин. 

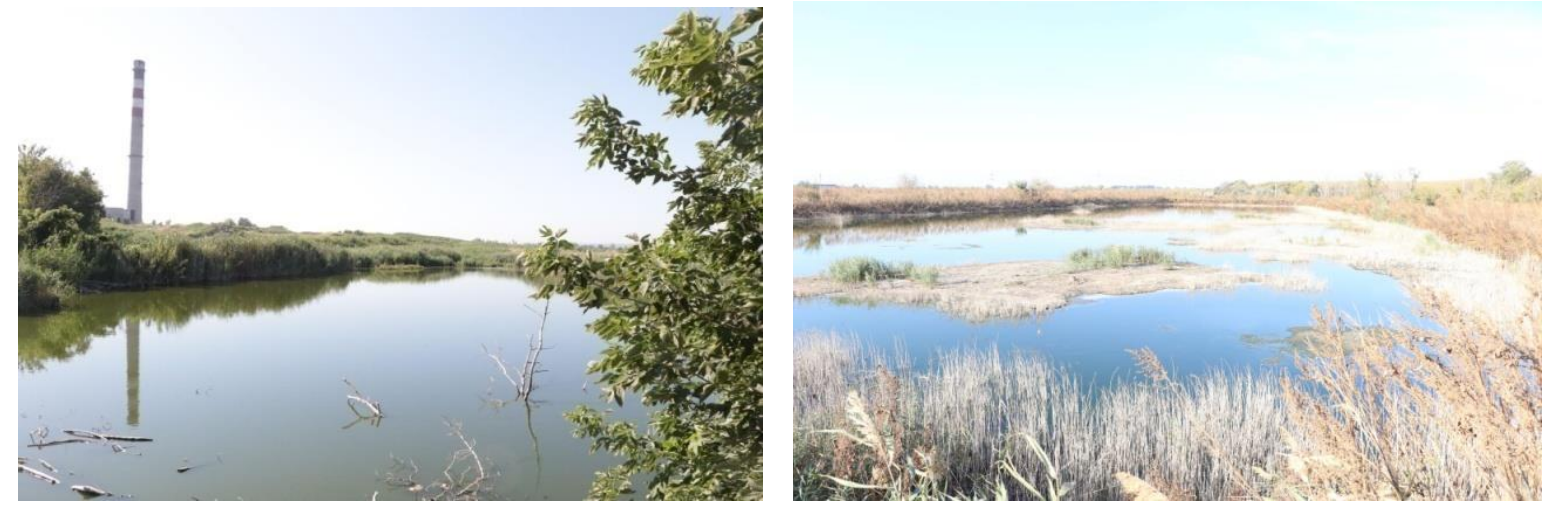

Рис. 3. Мулові майданчики очисного комплексу м. Харків - гніздові біотопи лиски

Терміни прильоту лиски на місця гніздування залежать від скутості водойми кригою, оскільки головним джерелом живлення лиски в цей період слугує підводна рослинність. Перші особини весною зареєстровано 11.03.2020, 3.04.2021.

Гнізда розташовані досить близько до лінії озерного ложе, де лиска проводить багато часу у пошуках корму. Частина обстежених гнізд побудовані на мілководді, у колонії мартина звичайного (Larus ridibundus L.). Всі досліджені 62 гнізда Fulica atra L. на озері Новий Лиман розташовані один від одного у середньому 12,5 м, іноді відстань становила не більше 5 м, а найбільша відстань - близько 20 м. 11 гнізд на мулових майданчиках очисного комплексу м. Харків розміщувались поодиноко. Під час будування гнізда лиска використовує листя рогозу та очерету, переплітаючи їх між собою. Гніздо птахи будували на заломах рослин, своєю основою воно, як правило, торкалось води (Рис 4a), іноді взагалі плавало (Рис 4b).
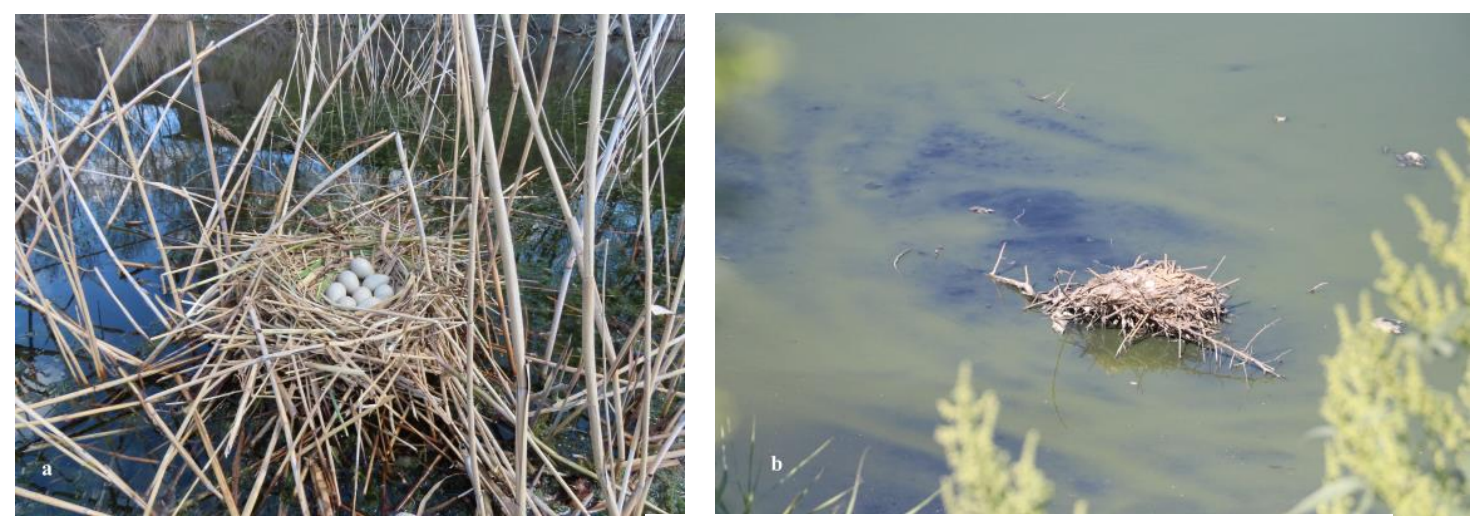

Рис. 4. Типи розміщення гнізд Fulica atra: на заломах рослин на озері (a) та плаваюче гніздо на мулових майданчиках очисних споруд (b)

Гнізда часто досить глибокі, охайні, сухі. Один бік гнізда у процесі відвідування птахами, часто має пологий нахил. Іноді до гнізда вимощена доріжка із заломлених рослин, яка може бути досить довгою, за нашими спостереженнями, близько 1,5 м. Середні розміри гнізд (n=15): зовнішній діаметр (D) - 39,6 2 ,96 см, внутрішній діаметр (d) $-25,4 \pm 1,34 \mathrm{~cm}$, висота (h) $-16,2 \pm 0,90 \mathrm{~cm}$.

Лиска приступає до гніздування досить рано і навіть, низька нічна температура $\left(+3^{\circ} \mathrm{C}\right.$ спостерігалась у квітні 2021 року) не стає на заваді для початку відкладання яєць. Відкладання яєць починається у другій декаді квітня (перші яйця відкладені 17-18 квітня) і триває до середини червня. Найактивніша фаза відкладання яєць припадає на III декаду квітня, коли середньодобова температура становить $14,45 \pm 3,56^{\circ} \mathrm{C}$ вдень та $3,0 \pm 2,41^{\circ} \mathrm{C}$ вночі (Рис. 5). Температурні дані використані з сайту meteopost.com [17]. На початку липня (08.07.2021p.) зареєстровано поодинокі кладки на озері Новий Лиман. 


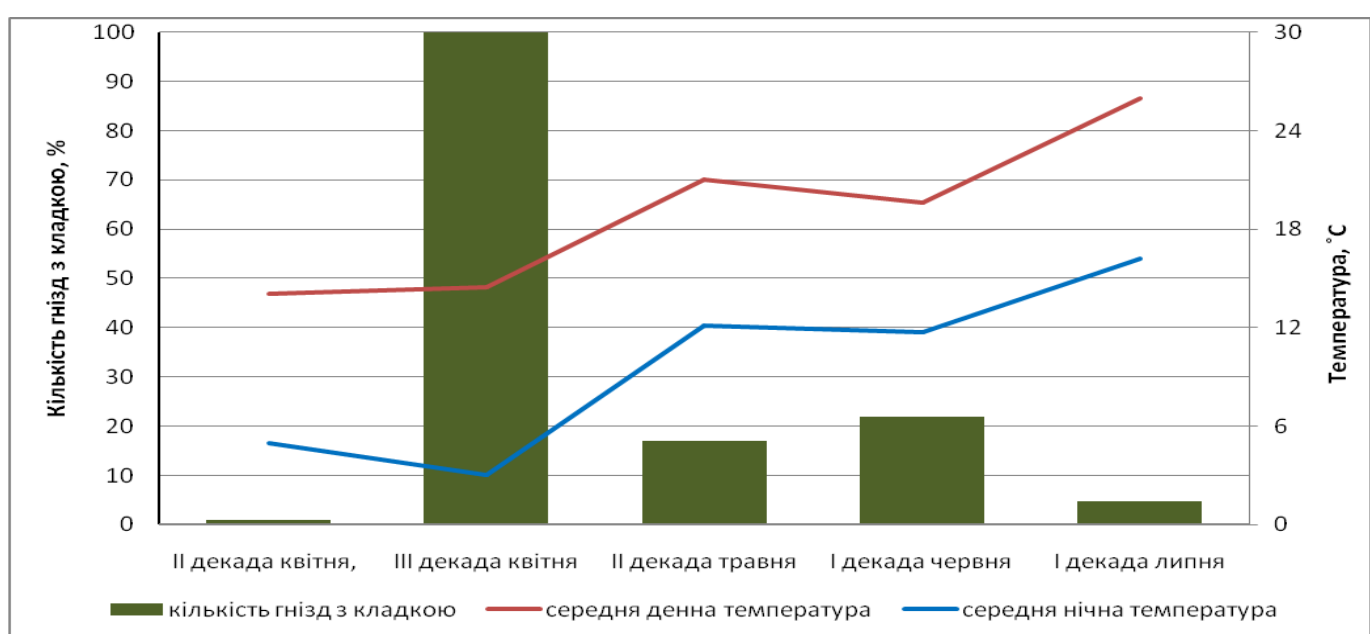

Рис. 5. Залежність відкладання яєць лиски Fulica atra L. від середньодобової температури на Озері Новий Лиман у 2021 році

Перші кладки птахів 3 гніздами на стадії відкладання першого яйця у 2020 р., спостерігали на озері з 25 квітня до 27 травня, у 2021 р. - 315 квітня до 7 травня. У 2020 році на 5 майданчиках очисного комплексу знайдено та обстежено 7 гнізд; у 5 гніздах десять пташенят успішно вилупились та досягли дорослого віку. У 2021 році знайдено 4 гнізда, у яких успішно вилупилось 9 пташенят.

Загалом, у районі дослідження у кінці квітня-на початку травня 2021 p. всі знайдені гнізда мали завершену або майже повну кладку. Середня кількість яєць у кладці 7,1土1,13 (6 - 9), рідше 11.

Морфометричні показники яєць лиски на озері Новий Лиман (n=223): $53,33 \pm 2,41 \times 37,09 \pm 1,35$ (табл. 1.), суттєво не відрізняються від даних інших дослідників виду Fulica atra [20]. Основний фон забарвлення яєць лиски варіює між світло-глинястим чи пісочним, по якому розкидані дрібні фіолетові і коричневі крапки та невеликі плями (Рис 6).

Морфометричні показники яєць у кладках Fulica atra

\begin{tabular}{|l|c|c|c|}
\hline \multicolumn{1}{|c|}{ Показники } & $\begin{array}{c}\text { Мінімальне } \\
\text { значення }\end{array}$ & $\begin{array}{c}\text { Максимальне } \\
\text { значення }\end{array}$ & $\begin{array}{c}\text { Середнс } \\
\text { значення }\end{array}$ \\
\hline Довжина, L (мм) & 40,00 & 59,90 & $53,33 \pm 2,41$ \\
\hline Діаметр, В (мм) & 32,60 & 46,50 & $37,09 \pm 1,35$ \\
\hline Маса, $\mathrm{m}($ г) & 27,79 & 46,63 & $37,39 \pm 3,23$ \\
\hline${\left.\text { Об'єм, V (см }{ }^{3}\right)}^{\text {Індекс форми, } \mathrm{S}_{\mathrm{ph}}(\%)}$ & 7,38 & 13,28 & $10,05 \pm 0,97$ \\
\hline
\end{tabular}

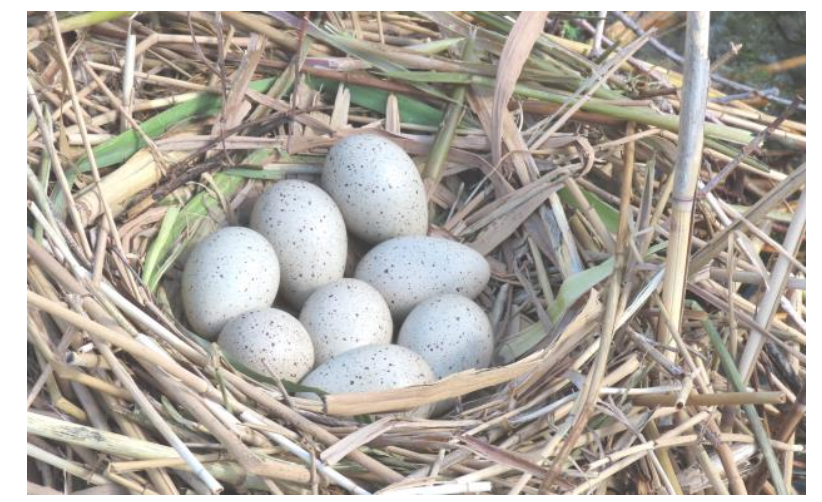

Рис. 6. Кладка яєць Лиски на озері Новий Лиман 
Перші два тижні після появи пташенят спостерігається розділення виводку на дві "родинні групи". Кожен з батьків веде по 3-5 пташенят, які плавають окремо, але об'єднуються під час відпочинку, ночівлі та при відході одного 3 партнерів на "патрулювання" чи захист кордонів своєї території (Рис 8).

На озері Новий лиман та мулових майданчиках, виводки пташенят знаходяться поряд зі своїми батьками у густих заростях, іноді виходять на відкритий простір для годування. При наближенні небезпеки, самка чи самець видають характерний звук, i пташенята швидко ховаються у хащі.

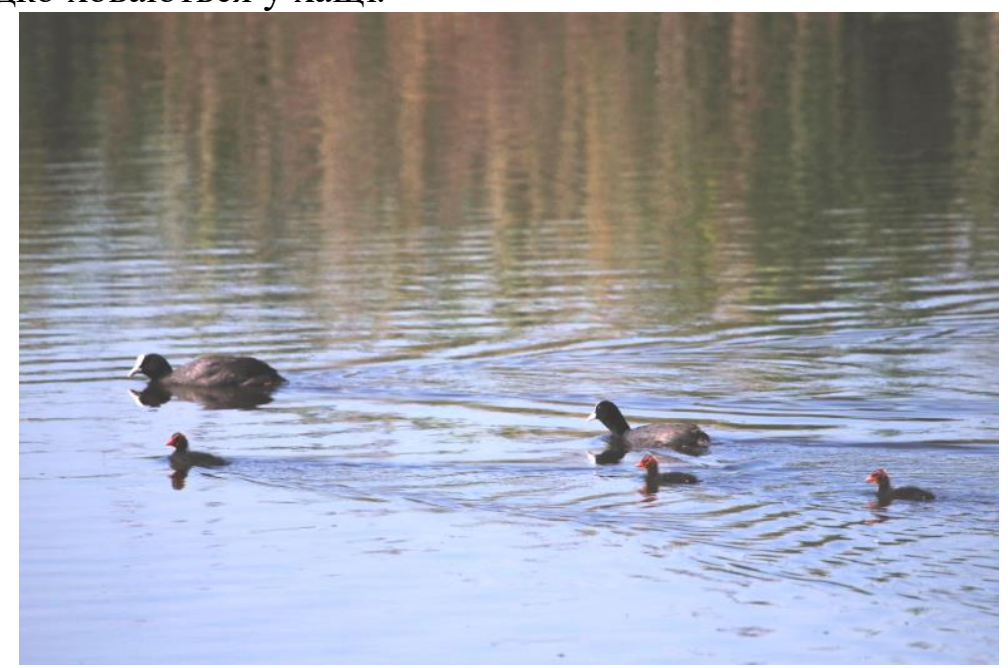

Рис. 7. Виводок Fulica atra на очисних спорудах

На успішність розмноження птахів на озері впливають ондатра болотяна (Ondatra zibethicus L..,1766), нутрія (Myocastor coypus Molina, 1782), видра річкова (Lutra lutra L., 1758), яких ми спостерігали на озері. У літературі $є$ данні про залежність популяції птахів від норки європейської (Mustela lutreola L., 1761) [18]. У присутності людини птахи втрачають пильність, у цей момент гнізда лиски можуть розорювати мартини, воронові. Крім того, над озером часто спостерігали хижаків: луня очеретяного (Circus aeruginosus L., 1758), канюка звичайного (Buteo buteo L., 1758 ), шуліку чорного (Milvus migrans Bodd, 1783), луня польового (Circus cyaneus L., 1766), яструба малого (Accipiter nisus L., 1758), орла - карлика (Hieraaetus pennatus Gmelin, 1788). Всі ці птахи мають вплив на успішність виживання пташенят. Присутність людини під час гніздування має негативний вплив на рівень та тривалість пильності птахів, їх поведінку при годуванні, не залежно від кількості пар у колонії [5].

\section{Висновки}

На озері Новий Лиман та мулових майданчиках міських очисних споруд, сприятливі умови для успішного розмноження Fulica atra, яка знаходиться під охороною Бернської та Боннської конвенцій. Виявлена чисельна популяція лиски, яка $€$ субдомінуючим видом серед водоплавних птахів. Щільність гніздування варіювала від 0,6 пар/га на мулових майданчиках до 3,6 пар/га на озері Новий Лиман. Середній розмір кладок становить $7,1 \pm 1,13(6-11)$.

\section{Список використаної літератури}

1. Банік М.В., Пономаренко О.Л., Атемасов А.А. Структура угруповань гніздових водоплавних i водно-болотяних птахів Приорелля та іiі зміни за останні десятиліття. Вісник Харківського національного університету імені В.Н. Каразіна. Серія: Біологія. Вип. 29. 2017.109-119.

2. Блум П.Н. Лысуха (Fulica atra L.) в Латвии. Рига. Зинатне. 1973. 156 с.

3. Брезгунова О.А. К вопросу о ночёвочном поведении лысухи (Fulica atra). Птицы бассейна Северского Донца. 2014. Вип. 12. С. 275-279. 
4. Бюллетень РОМ: Итоги среднезимних учетов водно-болотных птиц 2005, 2007-2010 годов в АзовоЧерноморском регионе Украины / Под ред. Ю. А. Андрющенко. 2011. Вып. 7. 64 с.

5. Walesiak M., Górecki G., and Brzeziński M. "Recovery of Eurasian Coot Fulica atra and Great Crested Grebe Podiceps cristatus Breeding Populations in an Area Invaded by the American Mink Neovison vison," Acta Ornithologica 54(1), (27 August 2019). 2019. P. 73-83/...https://doi.org/10.3161/00016454AO2019.54.1.007

6. Дебелий Я., Серебряков В. Особливості гніздової біології лиски Fulica atra L. на території Центральної України. Вісник Львівського ун-ту. Серія біологічна. Вип. 56. 2011. С. 186-192.

7. Дебелый Я.Ю., Серебряков В.В. О гнездовании и зимовке лысухи Fulica atra в Киеве. Русский орнитологический журнал. Том 21. Экспресс-выпуск 827. 2012. С. 3187-3189.

8. Ендрашко-Домбровска Д., Дэмбинска Д. Этологические и этологические аспекты приспособления лысухи (Fulika atra ) к жизни в городе. Русский орнтологический журнал. Экспересс-выпуск 28. 1997. С. 14-19.

9. Кошелев А. И. Лысуха в Западной Сибири (экология, поведение и хозяйсвенное значение): монография. Новосибирск: Наука, 1984. 176 с.

10. Кошелев А.И. Географическая изменчивость видовых параметров лысухи (Fulica atra L.) в Палеарктике. Вид и его продуктивность в ареале : материалы VI совещ. (Санкт-Петербург, 13-26 нояб. 1993 г.) Санкт-Петербург: Гидрометеоиздат, 1993. С. 104-106.

11. Кошелев А.И., Кошелев В.А. Поведение водоплавающих птиц в выводковый период на водоемах северного Приазовья. Вісті Біосферного заповідника "Асканія-Нова". 2016. Том 18. С. 67-7

12. Кузьменко В.В. Особенности экологии лысухи (Fulica atra L.) в Белорусском Поозерье. Вестн. Витебск. ун-та, 2002. Вып. 1 (23). С. 120-125.

13. Cramp S. (ed.) The Birds of Western Palearctic. Oxford Univ. 1992. P. 2.

14. Мянд Р. Внутрипопуляционная изменчивость птичьих яиц. Таллин: Вагус, 1988. 195 с.

15. Резанов А.Г. Оценка качественного разнообразия кормового поведения лысухи (Fulica atra) в пределах палеарктической части ареала. Бранта: Сборник научных трудов Азово-Черноморской орнитологической станции. 2003. Вип. 6. С. 96-107.

16. Сайт Птахи України https://aves.land.kiev.ua/

17. Сайт https://meteopost.com/

18. Severcan Ç \& Yamaç E. The effects of flock size and human presence on vigilance and feeding behavior in the Eurasian Coot (Fulica atra L.) during breeding season. Acta ethologica v. 14, 2011. P. 51-56

19. Halupka L., Czyż B \& Dominguez C. The effect of climate change on laying dates, clutch size and productivity of Eurasian Coots Fulica atra. International Journal of Biometeorology. V 64, 2020, P. 1857-1863.

20. Hoyt D. F.. Practical methods of estimating volume and fresh weight of bird eggs. Auk. Vol. 96, 1979. P. 73-77.

21. Шкарин В.С. Материалы по размножению, инкубации и эмбриональному развитию лысухи Fulica atra. Русский орнитологический журнал, Экспресс-выпуск 98. 2000. С. 3-16.

\section{References}

1. Banik, M.V., Ponomarenko, A.L., \& Atemasov, A.A. (2017). The structure of groups of nesting waterfowl and water-marsh birds of Priorell and its changes over the past decades. Visnyk Kharkivskoho natsionalnoho universytetu imeni V.N. Karazina [Bulletin of V.N. Karazin]. Series: Biology. 29.109-119. (in Ukr.).

2. Bloom, P.N. (1973). Coot (Fulica atra L.) in Latvia. Riga. Zinatne. 156. (in Rus.).

3. Brezgunova, O. A. (2014). On the question of the nocturnal behavior of the coot (Fulica atra). Ptitsyi basseyna Severskogo Dontsa [Birds of the Seversky Donets basin]. 12. 275-279. (in Rus.)

4. Byulleten ROM [ROM Bulletin]: (2011). Results of mid-winter surveys of waterbirds in 2005, 2007-2010 in the Azov-Black Sea region of Ukraine / Ed. Yu. Andryushchenko, A.. 7. 64. (in Rus.).

5. Walesiak, M., Górecki, G., \& Brzeziński, M. (2019). Recovery of Eurasian Coot Fulica atra and Great Crested Grebe Podiceps cristatus Breeding Populations in an Area Invaded by the American Mink Neovison vison. Acta Ornithologica 54(1), 73-83, (27 August 2019). /...https://doi.org/10.3161/00016454AO2019.54.1.007

6. Debeliy, Y., \& Serebryakov, V. (2011). Peculiarities of nesting biology of the fox Fulica atra L. on the territory of Central Ukraine. Visnyk Lvivskoho un-tu [Bulletin of Lviv University].Biological series. 56. 186-192. (in Ukr.).

7. Debely Ya.,Yu., \& Serebryakov, V.V. (2012). About nesting and wintering of coot Fulica atra in Kiev. Russkiy ornitologicheskiy zhurnal [Russian ornithological journal]. 21. 827. 3187-3189. (in Rus.).

8. Endrashko-Dombrovska, D., \& Dembinska, D. (1997). Ethological and ethological aspects of adaptation of the coot (Fulika atra) to life in the city. Russkiy ornitologicheskiy zhurnal [Russian orntological journal]. 28. 14-19. (in Rus.).

9. Koshelev, A.I. (1984). Lysukha in Western Siberia (ecology, behavior and economic significance): monograph. Novosibirsk: Nauka, 176. (in Rus.). 
10. Koshelev, A.I. (1993). Geographic variability of species parameters of coot (Fulica atra L.) in the Palaearctic. Species and its productivity in the area: materials of the VI meeting. (St. Petersburg, November 13-26, 1993) St. Petersburg: Gidrometeoizdat. 104-106. (in Rus.).

11. Koshelev, A.I., \& Koshelev, V.A. (2016). Behavior of waterfowl during the brood period in the water bodies of the northern Azov region. Visti Biosfernoho zapovidnyka "Askaniia-Nova" [Visti of the Biosphere Reserve "Askania-Nova"]. 18. 67-7 (in Rus.).

12. Kuzmenko, V.V. (2002). Features of the ecology of the coot (Fulica atra L.) in the Belarusian Poozerie. Vestnik Vitebskogo universiteta [Messenger Vitebsk University]. 1 (23). 120-125. (in Rus).

13. Cramp, S. (1992). The Birds of Western Palearctic. Oxford Univ. 2.

14. Myand, R. (1988). Intrapopulation variability of bird eggs. Tallinn: Vagus.195. (in Rus.).

15. Rezanov, A.G. (2003). Assessment of the qualitative diversity of foraging behavior of the coot (Fulica atra) within the Palaearctic part of the range. Branta: Sbornik nauchnyih trudov Azovo-Chernomorskoy ornitologicheskoy stantsii [Branta: Collection of Scientific Papers of the Azov-Black Sea Ornithological Station]. 6. 96-107. (in Rus.).

16. Bird of Ukraine website https://aves.land.kiev.ua/ (in Ukr.).

17. Website https://meteopost.com/

18. Severcan, Ç \& Yamaç, E. (2011). The effects of flock size and human presence on vigilance and feeding behavior in the Eurasian Coot (Fulica atra L.) during breeding season. Acta ethologica 14. 51-56.

19. Halupka, L., Czyż ,B \& Dominguez, C. (2020). The effect of climate change on laying dates, clutch size and productivity of Eurasian Coots Fulica atra. International Journal of Biometeorology. 64. 1857-1863.

20. Hoyt, D. F. (1979). Practical methods of estimating volume and fresh weight of bird eggs. Auk. 96. 73-77.

21. Shkarin, V.S. (2000). Materials on reproduction, incubation and embryonic development of coot Fulica atra. Russkiy ornitologicheskiy zhurnal [Russian Ornithological Journal]. 98. 3-16. (in Rus.).

\section{T. L. Yarmak, Y. P. Mamedova, A. B. Chaplyhina Breeding Biology of the Lald (Fulica atra L.) at the Water Treatment Facilities of the Kharkov City.}

Introduction. The anthropization of ecosystems is an important factor for the evolution of species and adaptation processes. Fulica atra L. is a fairly abundant species of wetlands in Ukraine. The adaptation of the coot to anthropogenic territories occurs during the winter period in cities, later birds remain in these areas for nesting.

Purpose. To assess the current state of the coot population at water treatment facilities and Lake Novy Liman, which are the parts of the territory of the city of Kharkov. Studies of nesting biology of Fulica atra on Lake Novy Liman and silt sites of treatment facilities make it possible to assess the current state of the population of the species in the water bodies of Kharkov, as well as important for completeness assessments of the distribution of birds in wetlands.

Methods. The studies were carried out in 2020-2021 during expedition trips to Lake Novy Liman and biological treatment facilities № 2 in Kharkov.

Results. The nesting biology of the coot (Fulica atra L.) was investigated at the silt sites of water treatment facilities of the biological treatment complex № 2 in Kharkov and Lake Novy Liman in April-June 2020-2021. The reproduction biology of 73 pairs of coot was studied. To set the nesting density, a map with the coordinates of the nests has been created. The first eggs in clutches were found on average on April 16 1,4 at an average daily temperature of $+5 \pm 1,73^{\circ} \mathrm{C}$ at night and $+20 \pm$ $0,89^{\circ} \mathrm{C}$ during the day in 2020 and on April $18 \pm 1,9$ at $+14,9 \pm 3,08^{\circ} \mathrm{C}$ during the day and $+5 \pm 2,76^{\circ} \mathrm{C}$ at night in 2021. Average clutch size 7,1 $\pm 1,13$ eggs. First chicks: May 8-10. Average egg size $(n=223): 53,37 \pm 2,56 \times 37,05 \pm 1,45 \mathrm{~mm}$. Vertebrates and birds of prey have been identified that can affect the breeding success of the coot.

Originality. For the first time, a study of the breeding biology of the coot was carried out on the territory of treatment facilities and their surroundings.

Conclusion. Wastewater treatment plants are an important place in the city of Kharkov, where birds undergo the process of adaptation to the anthropogenic landscape.

Key words: coot, nesting biology, egg laying, sewage treatment plants, Novy Lyman lake.

Одержано редакцією: $\quad 21.11 .21$

Прийнято до публікації: 13.12 .21 